\title{
EFFICACY OF THE SPIDER WEB METABOLITES ACTIVITY AGAINST MULTI DRUG RESISTANCE (MDR) BACTERIA
}

\author{
HAQ, I. U. ${ }^{1}$ - QASIM, M. ${ }^{1}$ - RAHIM, K. ${ }^{2,3 *}$ - AMEEN, F. ${ }^{4}$ - DAWOUD, T. ${ }^{4}$ - BASIT, A. ${ }^{5}$ - MUNIR, S. $^{6}-$ \\ ALSHEHREI, F. ${ }^{7}$ \\ ${ }^{1}$ Department of Microbiology, Kohat University of Science and Technology (KUST), Khyber \\ Pakhtunkhwa Kohat 26000, Pakistan \\ ${ }^{2}$ Department of Microbiology, Cholistan University of Veterinary and Animal Sciences (CUVAS), \\ Punjab, Bahawalpur 63100, Pakistan \\ ${ }^{3}$ Beijing Key Laboratory of Genetic Engineering Drug and Biotechnology, Institute of Biochemistry \\ and Biotechnology, College of Life Sciences, Beijing Normal University, Beijing 100875, China \\ ${ }^{4}$ Department of Botany \& Microbiology, College of Science, King Saud University, Riyadh 11451, \\ Saudi Arabia \\ ${ }^{5}$ State Key Laboratory of Agro-Biotechnology, College of Biological Sciences, China Agricultural \\ University, Beijing, China \\ ${ }^{6}$ Faculty of Plant Protection, Yunnan Agricultural University, Kunming 650201, Yunnan, China \\ ${ }^{7}$ Department of Biology, Jumom College Umm Al-Qura University Makkah 21955, Saudi Arabia \\ *Corresponding author \\ e-mail:kashifrahim@cuvas.edu.pk, kashifbangash073@gmail.com
}

(Received 24 $4^{\text {th }}$ Mar 2019; accepted $2^{\text {nd }}$ Jul 2019)

\begin{abstract}
Antibiotic resistance, which is emerging among pathogenic bacteria, is a leading cause of treatment failure worldwide with particular reference to developing countries. Thus, there is a need to explore and discover novel antimicrobial agents. The objective of this study was to investigate antibacterial activity of spider web metabolites and characterize certain antibacterial compounds. Web solvent extract (methanol, ethanol and acetone) was biologically screened for antibacterial activity against seven multiple drug resistant bacteria including three Gram negative bacteria (E. coli, A. baumannii, and S. typhi) and four gram positive bacteria (S. aureus, Bacillus, E. faecalis and S. pneumonae) using well diffusion test. Solvent extracts with the concentrations of $(3.3 \mathrm{mg} / \mathrm{ml} 4.95 \mathrm{mg} / \mathrm{ml} 6.6 \mathrm{mg} / \mathrm{ml} 8.25 \mathrm{mg} / \mathrm{ml}$ $9.9 \mathrm{mg} / \mathrm{ml}$ and $11.55 \mathrm{mg} / \mathrm{ml}$ ) were used to check the efficiency against MDR bacteria. Solvent extract of web metabolites exhibited significant activity against all seven MDR bacteria, by producing clear growth inhibition zones ranging in diameter from 04 to $22 \mathrm{~mm}$. Considerable activities was exhibited against $E$. faecalis $(22 \mathrm{~mm})$, E. coli $(14 \mathrm{~mm})$ and $S$. typhi $(15 \mathrm{~mm})$. Acetone solvent extracts showed high antibacterial activity against most MDR bacteria. Solvent extracts with concentrations less than $5 \mathrm{mg} / \mathrm{ml}$ did not exhibit sufficient activity. Higher activities were related to concentrations higher than $6 \mathrm{mg} / \mathrm{ml}$. Findings of the current study indicated that spider web metabolites may show promising antimicrobial activity against MDR bacteria. Additionally, the results suggest that spider web may be a broad spectrum antimicrobial agent, wherein its individual constituents contribute to its antimicrobial activity.
\end{abstract}

Keywords: antibiotics resistance, antibacterial metabolites, solvent extracts, MDR, Pakistan

\section{Introduction}

A lack of proper antimicrobial agents capable of controlling the incidence of infectious diseases is a major issue facing the health sector worldwide. An increase in 
microbial diseases resistant to antibiotics has reached worrisome proportions in the biosciences field (Cassini et al., 2018). Discovery of the first antibiotic, followed by technological advances in antimicrobial drug research, led to the protection of millions from microbial diseases. In the history of antibiotics, the first ever contribution was made by Sir Alexander Fleming who, in 1928, discovered that Penicillin derived from molds was capable of inhibiting bacteria. Following the discovery of this highly appreciated antibiotic, several other antibiotics were also discovered and used to treat infectious diseases (Davies et al., 2010). However, towards the end of the 1900s, emergence of antimicrobial resistant species together with the capacity for resistant gene transfer between species became a cause for major concern in the life sciences community (Amare et al., 2011). The Emergence of MDR bacteria capable of resisting antibiotics directly and indirectly is the direct result of all these factors. Furthermore, extensive use of antibiotics during the past few decades, led to the application of selective pressure on vulnerable bacteria, favouring the survival of resistant strains, few of which are resilient to more than one antibiotic (Arason et al., 2002).

The emergence of MDR bacterial species increased gradually over the years. Currently numerous studies have described various pathogenic bacterial species including Salmonella typhi, Acinetobacter baumannii, Staphylococcus aureus, Enterococcus faecalis, Streptococcus pneumonae and Escherichia coli as highly antimicrobial resistant. These bacteria, which cause many different infectious diseases, are resistant to multiple antibiotics and cannot be treated with traditional antibiotics as reported in many studies (Singhal, 2014; Doi, 2015; Da Silva, 2016; Megan, 2016; Nilsson, 2012; Wattanathum, 2003; Noble, 1992). These strains may be untreatable in the near future unless substitute or novel antimicrobials are developed. Novel antibiotics may be derived from natural sources such as plants, animals or their secretions in the form of molecules and compounds. Spider web metabolites comprise different molecules which appear to be antimicrobial according to studies (Vollrath et al., 2000). Spider silk is also attracting attention due to its antimicrobial properties. There have been unsubstantiated reports regarding the antimicrobial potential of spider silk (Wright et al., 2012). This report indicated that microbes were unable to grow on spider silk due to its acidic properties, suggesting that spider silk either prevented. Biofilm formation by microorganisms or were bacteriostatic or bactericidal in nature (Saleem et al., 2010). Additionally, bacteriostatic activity of spider silk has also been attributed to the presence of potassium nitrate, which inhibits the growth of microbes such as Bacillus subtilis and E. coli (Chakraborty et al., 2009). Antibacterial and antifungal activity of spider webs is mentioned in literature. However, antimicrobial potential of spider webs against multi drug resistant bacteria (MDR) has not yet been examined in Pakistan. Multi-drug resistant (MDR) organisms are a global threat. Antibiotic resistance accounts for hundreds of thousands of deaths annually (Johan et al., 2018). Spider web been traditionally used as an antiseptic in rural areas of Pakistan, while Atypus spider webs were used by people in the Carpathian Mountains as a topical antiseptic (Wright et al., 2012). This was considered to be helpful as a disinfectant.

The aim of this study was to investigate antibacterial activity of spider web metabolites and characterize certain antibacterial compounds. Different concentrations of web extract were used against previously identified MDR bacteria. This study will be helpful to kill drug resistant bacteria and discovery of the novel antibiotics. 


\section{Materials and methods}

\section{Sampling}

The current study and sampling of web were done in the district Kohat, Khyberpakhtunkhwa, Pakistan. Previously identified and characterized clinical bacterial isolates of Salmonella typhi, Staphylococcus aureus, Enterococcus faecalis, Acinetobacter baumannii, bacillus, Streptococcus pneumonae, and Escherichia coli were recruited for this study. These previously identified isolates were basically from chronic wounds origin. The samples were forwarded for re-culturing and reidentification. Biochemical test used for identification are given in details in Table 1.

Table 1. Biochemical identification of test isolates

\begin{tabular}{c|c|c|c|c|c|c|c}
\hline \multirow{2}{*}{ Pathogens } & \multicolumn{2}{|c|}{ Cell morphology } & \multicolumn{5}{|c}{ Biochemical tests } \\
\cline { 2 - 8 } & Shape & Gram & Cat & Oxi & Ind & DNase & Cit \\
\hline Bacillus & Rod & $+\mathrm{ve}$ & $+\mathrm{ve}$ & variable & $-\mathrm{ve}$ & $-\mathrm{ve}$ & $+\mathrm{ve}$ \\
A. baumannii & Rod & $-\mathrm{ve}$ & $+\mathrm{ve}$ & $-\mathrm{ve}$ & $-\mathrm{ve}$ & $-\mathrm{ve}$ & $+\mathrm{ve}$ \\
S. Aureus & Cocci & $+\mathrm{ve}$ & $+\mathrm{ve}$ & $-\mathrm{ve}$ & $-\mathrm{ve}$ & $+\mathrm{ve}$ & $+\mathrm{ve}$ \\
S. Typhi & Rod & $-\mathrm{ve}$ & $+\mathrm{ve}$ & $-\mathrm{ve}$ & $-\mathrm{ve}$ & $-\mathrm{ve}$ & $-\mathrm{ve}$ \\
E. coli & Rod & $-\mathrm{ve}$ & $+\mathrm{ve}$ & $-\mathrm{ve}$ & $+\mathrm{ve}$ & $-\mathrm{ve}$ & $-\mathrm{ve}$ \\
S. pneumonae & Cocci & $+\mathrm{ve}$ & $-\mathrm{ve}$ & $-\mathrm{ve}$ & $-\mathrm{ve}$ & $-\mathrm{ve}$ & $-\mathrm{ve}$ \\
E. faecalis & Cocci & $+\mathrm{ve}$ & $+\mathrm{ve}$ & $-\mathrm{ve}$ & $-\mathrm{ve}$ & $-\mathrm{ve}$ & $+\mathrm{ve}$ \\
\hline
\end{tabular}

S. aureus = staphylococcus aureus, S. Typhi=salmonella typhi, S. Pneumonae = streptococcus Pneumonae, E. faecalis $=$ Enterococcus faecalis. $\quad$ Cat $=$ catalase,$\quad$ Cit $=$ citrate,$\quad$ Ind $=$ indole, Oxi $=$ oxidase

\section{Antibiotic resistance patterns}

Antibiotic resistance patterns of the isolates were determined via the Kirby-Bauer disk diffusion method (Bauer et al., 1966) according to the recommendations of the Clinical and Laboratory Standard Institute (CLSI) (Shallu et al., 2015). The isolates were treated with a total of 11 antibiotics as follows; Clarithromycin, Doxycycline, Cefoperazone sulbactam, Cefoxitin, Kanamycin, Nitrofurantoin, Penicillin, Levofloxacin, Ciprofloxacin, Oxacillin and Clarithromycin. Briefly, Mullen-Hinton agar was prepared. A $0.5 \mathrm{McFarland}$ turbidity standard equivalent to inoculation of a bacterial suspension was prepared and inoculated. Following $48 \mathrm{~h}$ of incubation, the diameters of inhibition zones around the disks were measured using a graduated ruler and results were interpreted according to CLSI guidelines.

\section{Collection, processing and metabolites of spider web}

Spider webs were collected from garages and ceilings of unused buildings in the district of Kohat, Pakistan. Webs were washed with distilled water in the laboratory and cleansed of other redundant ingredients and dust. Clean and wrapped web was air-dried at room temperature and preserved in ampoules. Organic solvents, such as methanol, ethanol and acetone, were screened for possible extraction of web metabolites which were to be tested against MDR species or specific pathogens considered sufficiently important or suitable for exploration (Tshipamba et al., 2018). 
Pure web metabolites were extracted using standard methodology. Pure web portions weighing $6 \mathrm{~g}$ each were introduced into falcon tubes, each containing $60 \mathrm{~mL}$ of acetone, methanol, ethanol and distilled water, and set on an orbital shaker at different angles for 2 weeks. After shaking liberated excessive amounts of metabolites, solvents were filtered into a beaker. The filtrate of solvent extract was placed in a large beaker and allowed to evaporate for one week. Following evaporation, the solidified extract was dissolved in $6 \mathrm{~mL}$ DMSO and kept it in sterile falcon tubes.

\section{Screening of webs}

Biological screening of antimicrobial properties of the web metabolites was performed via the well diffusion method. Muller Hinton Agar (MHA) media was used to assess susceptibility patterns of isolated bacteria by applying solvent extracts using well diffusion (Jaja et al., 2018).

\section{Results}

All isolates of S. typhi, S. aureus, E. faecalis, A. baumannii, bacillus, S. pneumonae and $E$. coli were re-identified via culture characterization, gram staining and biochemical testing.

\section{Antimicrobial sensitivity pattern of bacterial isolates}

Antimicrobial patterns of isolated bacterial pathogens were determined using 11 different antibiotic groups. E. coli, S. typhi and A. baumannii showed resistance to 7 antibiotics widely used against these pathogens, whereas $S$. aureus was resistant to 8 antibiotics. S. pneumonae was resistant to 6 antibiotics. However, Bacillus and E. faecalis were resistant to 6 antibiotics (Table 2). After confirming MDR patterns of these pathogens, aqueous acetone, ethanol, and methanol extracts of spider web were evaluated in vitro against Acinetobacter, bacillus, S. aureus, S. typhi, E. faecalis, $S$. pneumonae and E. coli.

Table 2. Assessment of test isolates

\begin{tabular}{c|c|c|c|c|c|c|c}
\hline Antibiotics & E. coli & E. faecalis & S. aureus & Bacillus & Acinetobacter & S. typhi & S. pneumonae \\
\hline Chloramphenicol $(30 \mu \mathrm{g})$ & $\mathrm{NA}$ & $\mathrm{R}$ & $\mathrm{R}$ & $\mathrm{I}$ & $\mathrm{NA}$ & $\mathrm{R}$ & $\mathrm{R}$ \\
Clarithromycin $(2 \mu \mathrm{g})$ & $\mathrm{S}$ & $\mathrm{I}$ & $\mathrm{I}$ & $\mathrm{R}$ & $\mathrm{R}$ & $\mathrm{I}$ & $\mathrm{I}$ \\
Oxacillin $(5 \mu \mathrm{g})$ & $\mathrm{S}$ & $\mathrm{R}$ & $\mathrm{R}$ & $\mathrm{R}$ & $\mathrm{R}$ & $\mathrm{R}$ & $\mathrm{R}$ \\
Doxycycline $(30 \mu \mathrm{g})$ & $\mathrm{R}$ & $\mathrm{R}$ & $\mathrm{R}$ & $\mathrm{R}$ & $\mathrm{I}$ & $\mathrm{R}$ & $\mathrm{R}$ \\
SCF $(105 \mu \mathrm{g})$ & $\mathrm{I}$ & $\mathrm{S}$ & $\mathrm{S}$ & $\mathrm{S}$ & $\mathrm{R}$ & $\mathrm{S}$ & $\mathrm{S}$ \\
Cefoxitin $(30 \mu \mathrm{g})$ & $\mathrm{R}$ & $\mathrm{I}$ & $\mathrm{I}$ & $\mathrm{R}$ & $\mathrm{R}$ & $\mathrm{R}$ & $\mathrm{R}$ \\
Kanamycin $(30 \mu \mathrm{g})$ & $\mathrm{R}$ & $\mathrm{I}$ & $\mathrm{R}$ & $\mathrm{R}$ & $\mathrm{R}$ & $\mathrm{R}$ & $\mathrm{R}$ \\
Nitroforantoin $(300 \mu \mathrm{g})$ & $\mathrm{I}$ & $\mathrm{R}$ & $\mathrm{R}$ & $\mathrm{I}$ & $\mathrm{I}$ & $\mathrm{I}$ & $\mathrm{I}$ \\
Penicillin $(6 \mu \mathrm{g})$ & $\mathrm{R}$ & $\mathrm{R}$ & $\mathrm{R}$ & $\mathrm{R}$ & $\mathrm{R}$ & $\mathrm{R}$ & $\mathrm{R}$ \\
Levofloxacin $(5 \mu \mathrm{g})$ & $\mathrm{R}$ & $\mathrm{S}$ & $\mathrm{S}$ & $\mathrm{S}$ & $\mathrm{I}$ & $\mathrm{S}$ & $\mathrm{S}$ \\
Ciprofloxacin $(5 \mu \mathrm{g})$ & $\mathrm{S}$ & $\mathrm{S}$ & $\mathrm{R}$ & $\mathrm{S}$ & $\mathrm{R}$ & $\mathrm{S}$ & $\mathrm{I}$ \\
\hline
\end{tabular}

$\mathrm{R}=$ Resistant $\mathrm{I}=$ Intermediate, $\mathrm{S}=$ Sensitive, $\mathrm{SCF}=$ Cefoperazonesulbactum. NA = not applicable 


\section{Antimicrobial activity of solvent extract against MDR bacteria}

A total of 6 trials were conducted to test the anti-MDR effects of web, using different solvent concentrations against each MDR bacterium. Following $24 \mathrm{~h}$, a significant portion of $9.9 \mathrm{mg} / \mathrm{ml}$ and $11.55 \mathrm{mg} / \mathrm{ml}$ solvent extract concentrations showed prolific activity while those concentrations that were less than $9.9 \mathrm{mg} / \mathrm{ml}$ did not display sufficient activity. Activity was measured by zone of inhibition around the wells. The highest inhibition zone $(22 \mathrm{~mm})$ was recorded for E. faecalis while the lowest zone (04 mm) was formed against E. coli (Fig. 1).

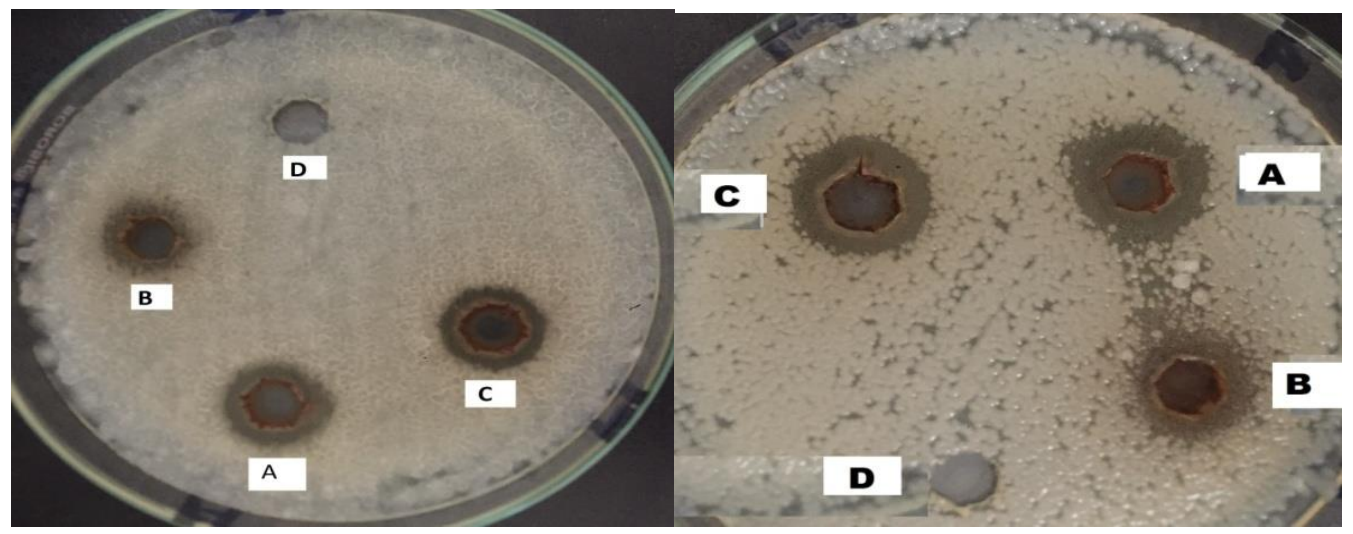

Figure 1. Antimicrobial activity of the spider web was evaluated by means of well diffusion method by using different organic solvents acetone, ethanol and methanol as compared with control respectively $(A, B, C$ and $D)$. The web extract residues with different concentration $(3.3 \mathrm{mg} / \mathrm{ml} 4.95 \mathrm{mg} / \mathrm{ml} 6.6 \mathrm{mg} / \mathrm{ml} 8.25 \mathrm{mg} / \mathrm{ml} 9.9 \mathrm{mg} / \mathrm{ml}$ and $11.55 \mathrm{mg} / \mathrm{ml}$ ) showed promising activity. The presence of inhibition zones was measured, recorded and considered as indication for antibacterial activity. After $24 \mathrm{~h}$ a significant fragment of trials $9.9 \mathrm{mg} / \mathrm{ml}$ and $11.55 \mathrm{mg} / \mathrm{ml}$ solvent extract concentration showed proficient activity while the rest less than $9.9 \mathrm{mg} / \mathrm{ml}$ did not show enough activity. Activity was measured by zone of inhibition around the wells. The highest zone of inhibition $(22 \mathrm{~mm})$ was recorded for Enterococcus faecalis while lowest zone (04 $\mathrm{mm}$ ) was formed against $E$. coli

Anti-MDR bacterial potential of spider web metabolite extracts of the organic solvents acetone, ethanol, and methanol was analyzed. Solidified solvent extracts were dissolved in DMSO. An extract of distilled water was incorporated as the negative control. Results were described based on two parameters; organic solvents, and solvent extract concentrations.

\section{Screening based on organic solvents}

Spider silk was screened using different organic solvents to extract the web metabolites.

\section{(i) Acetone}

Acetone extract showed activity against all MDR bacteria, but higher activity was recorded against E. coli, E. faecalis, and S. aureus. The highest zone of inhibition $(15 \mathrm{~mm})$ was recorded for E. coli, whereas E. faecalis, S. aureus, and S. typhi each 
exhibited $12 \mathrm{~mm}$ inhibitory zones on average. Inhibitory zones of 10, 09, and $07 \mathrm{~mm}$ were recorded for Bacillus, S. pneumonae and A. baumannii, respectively (Table 3).

Table 3. Antimicrobial activity of web with the acetone extract

\begin{tabular}{c|c|c|c|c|c|c}
\hline \multirow{2}{*}{ Pathogens } & \multicolumn{6}{|c}{ Zone of inhibition (mm) of acetone extract } \\
\cline { 2 - 7 } & $\mathbf{3 . 3} \mathbf{~ m g} / \mathbf{m l}$ & $\mathbf{4 . 9 5} \mathbf{~ m g / m l}$ & $\mathbf{6 . 6} \mathbf{~ m g} / \mathbf{m l}$ & $\mathbf{8 . 2 5} \mathbf{~ m g / m l}$ & $\mathbf{9 . 9} \mathbf{~ m g} / \mathbf{m l}$ & $\mathbf{1 1 . 5 5} \mathbf{~ m g / m l}$ \\
\hline Bacillus & - & - & - & - & - & 10 \\
S. aureus & - & - & - & 7 & 9 & 12 \\
S. typhi & - & - & - & 8 & - & 12 \\
Acinetobacter & - & - & - & - & 7 & 9 \\
E. faecalis & - & - & - & 13 & 13 & 13 \\
E. coli & - & - & - & 14 & 14 & 15 \\
S. pneumonae & - & - & - & - & 05 & 07 \\
\hline
\end{tabular}

\section{(ii) Ethanol}

Ethanolic extract showed the highest inhibition zone $(17 \mathrm{~mm})$ against bacillus. The second highest zone of inhibition $(15 \mathrm{~mm})$ was recorded for A. baumannii. However, the inhibitory zones of $S$. aureus, $S$. typhi and E. coli were 12,10 and $10 \mathrm{~mm}$, while $S$. pneumonae showed resistance upto some extent, its zone of inhibition was $08 \mathrm{~mm}$. $E$. faecalis appeared to be resistant to ethanol extract as shown (Table 4)

Table 4. Antimicrobial activity of web with the ethanol extract

\begin{tabular}{c|c|c|c|c|c|c}
\hline \multirow{2}{*}{ Pathogens } & \multicolumn{6}{|c}{ Zone of inhibition (mm) of ethanolic extract } \\
\cline { 2 - 7 } & $\mathbf{3 . 3} \mathbf{~ m g / m l}$ & $\mathbf{4 . 9 5} \mathbf{~ m g / m l}$ & $\mathbf{6 . 6} \mathbf{~ m g / m l}$ & $\mathbf{8 . 2 5} \mathbf{~ m g / m l}$ & $\mathbf{9 . 9} \mathbf{~ m g / m l}$ & $\mathbf{1 1 . 5 5} \mathbf{~ m g / m l}$ \\
\hline Bacillus & - & - & - & - & 16 & 17 \\
S. aureus & - & - & 07 & 09 & 10 & 12 \\
S. typhi & - & - & - & 05 & 05 & 10 \\
Acinetobacter & - & - & - & - & - & 15 \\
E. faecalis & - & - & - & - & - & - \\
E. coli & - & - & - & - & 7 & 10 \\
S. pneumonae & - & - & - & - & 5 & 8 \\
\hline
\end{tabular}

(iii) Methanol

The highest zone with methanol was recorded against E. faecalis $(22 \mathrm{~mm})$. Methanolic extracts showed average class inhibition zones against other MDR bacteria as follows; S. aureus $(12 \mathrm{~mm})$, Bacillus $(13 \mathrm{~mm})$, and A. baumannii and S. typhi $11 \mathrm{~mm})$. The lowest inhibitory zones $(06 \mathrm{~mm})$ were recorded for $E$. coli and $S$. pneumonae (Table 4).

\section{Screening based on solvent concentration}

Web solvent extracts with the following solvent concentrations were tested; $3.3 \mathrm{mg} / \mathrm{ml}, 4.95 \mathrm{mg} / \mathrm{ml}, 6.6 \mathrm{mg} / \mathrm{ml}, 8.25 \mathrm{mg} / \mathrm{ml}, 9.9 \mathrm{mg} / \mathrm{ml}$ and $11.55 \mathrm{mg} / \mathrm{ml}$. Sufficient activity was recorded only for concentrations ranging from 9.9 to $11.55 \mathrm{mg} / \mathrm{ml}$. 


\section{(i) Inhibition zones with $11.55 \mathrm{mg} / \mathrm{ml}$}

The highest inhibition zone $(22 \mathrm{~mm})$ was recorded for the concentration of $11.55 \mathrm{mg} / \mathrm{ml}$ for $E$. faecalis with the methanolic extract, whereas the second highest zone of inhibition was recorded for Bacillus $(17 \mathrm{~mm})$ with the ethanolic extract. Both $A$. baumannii and $E$. coli showed $15 \mathrm{~mm}$ inhibitory zones while the pathogens $S$. aureus and $S$. typhi showed zones of $12 \mathrm{~mm}$. Additionally, S. pneumonae showed a10 $\mathrm{mm}$ zone (Table 4).

\section{(ii) Inhibition zones with $9.9 \mathrm{mg} / \mathrm{ml}$}

Solvent extracts with concentrations of $9.9-11.55 \mathrm{mg} / \mathrm{ml}$ showed high efficiency. The highest inhibition zone $(16 \mathrm{~mm})$ was recorded for Bacillus with ethanolic extract. $E$ coli appeared to be more susceptible to acetone extract of $9.9 \mathrm{mg} / \mathrm{ml}$ as it produced a zone of $14 \mathrm{~mm}$. Another high inhibition zone $(13 \mathrm{~mm})$ was recorded for E. faecalis, while $11 \mathrm{~mm}$ inhibitory zones were observed against $S$. typhi and $S$. aureus and 06 and $07 \mathrm{~mm}$ inhibitory zones were recorded for $A$. baumannii and $S$. pneumonae, respectively (Tables 3, 4 and 5).

Table 5. Antimicrobial activity of web with the methanol extract

\begin{tabular}{c|c|c|c|c|c|c}
\hline \multirow{2}{*}{ Pathogens } & \multicolumn{6}{|c}{ Zone of inhibition (mm) of methanol extract } \\
\cline { 2 - 7 } & $\mathbf{3 . 3} \mathbf{~ m g} / \mathbf{m l}$ & $\mathbf{4 . 9 5} \mathbf{~ m g / m l}$ & $\mathbf{6 . 6} \mathbf{~ m g} / \mathbf{m l}$ & $\mathbf{8 . 2 5} \mathbf{~ m g} / \mathbf{m l}$ & $\mathbf{9 . 9} \mathbf{~ m g} / \mathbf{m l}$ & $\mathbf{1 1 . 5 5} \mathbf{~ m g / m l}$ \\
\hline Bacillus & & & & & 10 & 12 \\
S. aureus & & & & & 11 & 13 \\
S. typhi & - & - & - & 07 & 11 & 11 \\
Acinetobacter & - & - & - & - & - & 11 \\
E. faecalis & - & - & - & - & 08 & 22 \\
E. coli & - & - & - & - & 04 & 06 \\
S. pneumonae & - & - & - & - & 06 & 06 \\
\hline
\end{tabular}

\section{Discussion}

Accessibility to various antibiotics following the initial discovery of penicillin, initiated great enthusiasm in modern medicine (Sulaiman et al., 2014). The discovery of antimicrobials was one of the noteworthy discoveries in the history of microbial diseases. Following the discovery of antibiotics, humans became mostly free of harmful, deadly diseases. As a result of this medical miracle, people are able to live safe and healthy lives (Levy and Marshall, 2004). Currently, scientists are searching for natural sources of antibiotics that may help to develop antimicrobial agents against MDR bacteria. Novel antimicrobials have always been developed from natural sources. These sources may be microorganisms, plants and animals such as spiders and their metabolites. Spider silk is frequently cited as having antimicrobial properties in addition to several other scientifically verified biomedical properties (Chakraborty et al., 2009). Most studies on biomedical and mechanical properties of spider webs also mention their antimicrobial properties. Several studies describing antimicrobial properties of spider webs, may surface in literature reviews but these properties have not been tested against MDR bacteria. To our knowledge, this is the first study which addresses this crucial issue. 
In this study, silk of common house spiders was investigated for its qualitative antimicrobial potential. Aqueous, acetone, ethanol and methanol web extracts were tested against MDR bacteria including S. typhi, S. aureus, E. faecalis, A. baumannii, bacillus, S. pneumonae and E. coli. We determined that silk from the common house spider may act as an antimicrobial agent under various in vitro conditions. The studies related to antimicrobial potential of spider silk has been previously reported (Saleem, 2010; Laxminarayan, 2003). Web solvent extracts appear to be effective against all the MDR bacteria. Maximum inhibitory effects of all bacteria corresponded to concentrations ranging from $9.9 \mathrm{mg} / \mathrm{ml}$ and $12.55 \mathrm{mg} / \mathrm{ml}$ following after $24 \mathrm{~h}$ incubation period.

The most significant inhibition zone $(17 \mathrm{~mm})$ corresponding to increased activity was recorded against bacillus following $24 \mathrm{~h}$ of incubation. However, after $24 \mathrm{~h}$, activity was not significant and decreased. Web extracts showed significant activity against E. coli, Bacillus, S. aureus and S. pneumonae as indicated by the diameter of their inhibition zones, which confirmed the findings of other studies, in which inhibition zones were; E. coli $(8 \mathrm{~mm})$ B. subtilis $(14 \mathrm{~mm}), S$. aureus $(16 \mathrm{~mm})$ and for Streptococcus species (12 mm) (Wright et al., 2012).

Among all MDR bacteria tested, $S$. aureus appears to be susceptible to minimum concentrations as well as maximum concentrations of solvent extracts. E. faecalis appears to be resistant to all solvent extracts to some extent.

Spider silk comprises certain constituents having antimicrobial potential such as potassium hydrogen phosphate, compound potassium nitrate and amino acids. These amino acids display broad spectrum activity, especially against a diverse group of microorganisms, including gram positive and gram negative bacteria and fungi (Gomes et al., 2011). Antimicrobial peptides bind to the lipid bilayer membrane of bacteria. Through this interaction bactericidal peptides attain an amphiphilic three-D configuration whereby its positive side interacts directly with negatively charged lipid head-groups resulting in the formation of pores in the bacterial membrane (Havard, 2006).

Thereby, potassium hydrogen phosphate lowers $\mathrm{pH}$ to approximately 4 by releasing protons into the aqueous solution, causing it to turn acidic. Such low $\mathrm{pH}$ prevents microorganisms from digesting web constituents (Case et al., 1999). Consequently, microorganisms are unable to degrade the web easily. Potassium nitrate is a web constituent that prevents protein from denaturing in the acidic condition. Therefore, the above stated components make spider silk a good agent for preservation.

Spider silk constituents show potential as novel preservative agents which may be useful in food, pharmaceutical and diary industries, among others. These are efficient and moderately in expensive with increased shelf life and reduced side effects. Silk producing genes of spiders may be manipulated to obtain higher yields of better quality silk, which may be utilized for industrial purposes.

\section{Conclusion}

Spider web metabolites used in this study displayed promising antimicrobial activity against MDR bacteria. Results indicate that spider web may function as a broad spectrum antimicrobial agent. Individual components responsible for its antimicrobial activity should be evaluated via cell culture assays for toxicity, as well as via NMR and HPLC for their molecular structure. 
Acknowledgements. This study was supported by King Saud University, Deanship of Scientific Research, College of Science Research Center.

Author contribution. All of the authors contributed equally in this project.

Conflict of interests. The authors confirm that this article content has no conflict of interests.

\section{REFERENCES}

[1] Amare, G. L., Abdurrahma, Z., Moges, B., Ali, J. S. (2011): Postoperative surgical site bacterial infections and drug susceptibility patterns at Gondar University Teaching Hospital, Northwest Ethiopia. - Journal of Bacteriology Parasitology 2: 126.

[2] Arason, V. A., Gunnlaugsson, A., Sigurdsson, J. A, Erlendsdottir, H., Gudmundsson, S., Kristinsson, S. (2002): Clonal spread of resistant pneumococci despite diminished antimicrobial use. - Microbiology Drug Resistance 8(3): 187-192.

[3] Bauer, A. W., Kirby. W. M., Sherris, J. C., Turck, M. (1966): Antibiotic susceptibility testing by a standardized single disk method. - American Journal of Clinical Pathology 45(4): 493-496.

[4] Case, S. T., Thornton, J. R. (1999): High molecular mass complexes of aquatic silk proteins. - International Journal of Biological Macromolecules 24(2-3): 89-101.

[5] Cassini, A., Colzani. E., Pini, A., Mangen, M. J., Plass, D., McDonald, S. A., Maringhini, G., Van, L. A., Haagsma, J. A., Havelaar, A. H., Kramarz, P. (2018): Impact of infectious diseases on population health using incidence-based disability-adjusted life years (DALYs): results from the Burden of Communicable Diseases in Europe study European Union and European Economic Area countries 2009 to 2013. - Euro Surveillance 23(16).

[6] Chakraborty, D., Das, S. (2009): Antibacterial activities of cobweb protein. - Clinical Microbiology and Infection 4: S1-678.

[7] Da, Silva, G. J., Domingues, S. (2016): Insights on the horizontal gene transfer of carbapenemase determinants in the opportunistic pathogen Acinetobacter baumannii. Microorganisms 4(3): 29 .

[8] Davies, J., Davies, D. (2010): Origins and evolution of antibiotic resistance. Microbiology Molecular Biology Reviews 74(3): 417.

[9] Doi, Y., Murray, G. L., Peleg, A. Y. (2015): Acinetobacter baumannii: evolution of antimicrobial resistance treatment options. - Seminars in Respiratory and Critical Care Medicenes 36: 85-98.

[10] Goms, S. C., Leonor, I. B., Mano, J. F., Reis, R. L., Kaplan, D. L. (2011): Antimicrobial functionalized genetically engineered spider silk. - Biomaterials 32(18): 4255-4266.

[11] Håvard, J., Pamela, H., Robert, E. W. (2006): Antimicrobial peptide agents. - Clinical Microbiology Reviews 19(3): 491-511.

[12] Jaja, I. F., Bhembe, N. L., Green, E., Oguttu, J., Muchenje, V. (2018): Molecular characterisation of antibiotic-resistant Salmonella enterica isolates recovered from meat in South Africa. - Acta Tropica 190: 129-136.

[13] Johan, B. P., Erik, K., Joakim, L. (2018): Environmental factors influencing the development and spread of antibiotic resistance. - FEMS Microbiology Reviews 42(1): fux 053 .

[14] Laxminarayan, R., Duse, A., Wattal, C., Zaidi, A. K., Wertheim, H. F., Sumpradit, N., Greko, C. (2013): Antibiotic resistance the need for global solutions. - Lancet Infectious Diseases 13(12): 1057.

[15] Levy, S. B., Marshall, B. (2004): Antibacterial resistance worldwide: causes, challenges and responses. - Nature Medicine 10(12s): S122.

[16] Megan, R. K., Alexander, E. P., Laynez, W., Annie, U. S., Sachinkumar, B. S., Timothy, D. S., Alexander, R. H. (2016): Development of an in vitro colonization model to 
investigate Staphylococcus aureus interactions with airway epithelia. - Cell Microbiology 18(5): 720-731.

[17] Nilsson, O. (2012): Vancomycin resistant enterococci in farm animals - occurrence and importance. - Infection Ecology and Epidemiology 2. DOI: 10.3402/iee.v2i0.16959.

[18] Noble, W. C., Virani, Z., Cree, R. G. (1992): Co-transfer of vancomycin and other resistance genes from Enterococcus faecalis NCTC 12201 to Staphylococcus aureus. FEMS Microbiology Letters 72(2): 195-198.

[19] Saleem, M., Nazir, M., Ali, M. S., Hussain, H., Lee, Y. S., Riaz, N., Jabbar, A. (2010): Antimicrobial natural products: an update on future antibiotic drug candidates. - Natural Product Reports 2 27: 238-254.

[20] Shallu, K., Pradeep, K. S., Cheshta, S., Anupam, P., Aradhana, M., Anil, K. J., Acques, F. M., Anuradha, C. (2015): Multidrug-Resistant Candida auris Misidentified as Candida haemulonii: Characterization by Matrix-Assisted Laser Desorption Ionization-Time of Flight Mass Spectrometry and DNA Sequencing and Its Antifungal Susceptibility Profile Variability by Vitek 2, CLSI Broth Microdilution, and Etest Method. - Journal of Clinical Microbiology 53(6): 1823-1830.

[21] Singhal, L., Gupta, P. K., Kale, P., Gautam, V., Ray, P. (2014): Trends in antimicrobial susceptibility of Salmonella Typhi from North India (2001-2012). - Indian Journal of Medical Microbiology 3(2): 149.

[22] Sulaiman, A. A., Milton, W., Tahani, A. A., Hashim, B. S., Asmaa, A. F., Arunachalam, C. (2014): What if Fleming had not discovered penicillin? - Saudi Journal of Biological Sciences 21(4): 289-293.

[23] Tshipamba, M. E., Lubanza, N., Adetunji, M. C., Mwanza, M. (2018): Molecular characterization and antibiotic resistance of foodborne pathogens in street-vended readyto-eat meat sold in South Africa. - Journal of Food Protection 81(12): 1963-1972.

[24] Wattanathum, A., Chaoprasong, C., Nunthapisud, P., Chantaratchada, S., Limpairojn, N., Jatakanon, A., Chanthadisai, N. (2003): Community acquired pneumonia in Southeast Asia: the microbial differences between ambulatory and hospitalized patients. - Chest 123(5): 1512-1519.

[25] Wright, S., Goodacre, S. L. (2012): Evidence for antimicrobial activity associated with common house spider silk. - BMC Research Notes 5: 326.

[26] Vollrath, F. (2000): Strength and structure of spiders' silks. - Review Molecular Biotechnology 74(2): 67-83. 